\title{
The importance of Pediatric Dentistry in identifying child sexual abuse situations
}

\author{
A importância da Odontopediatria na identificação de situações de abuso sexual infantil \\ La importancia de la Odontología Pediátrica em la identificación de situaciones de abuso sexual \\ infantil
}

Received: 08/07/2021 | Reviewed: 08/12/2021 | Accept: 08/14/2021 | Published: 08/16/2021

\author{
ORCID: https://orcid.org/0000-0001-6629-0627 \\ Soberana Faculdade de Saúde de Petrolina, Brazil \\ E-mail: emillymaagalhaes@gmail.com \\ Camilla Thaís Duarte Brasileiro \\ ORCID: https://orcid.org/0000-0001-7041-3087 \\ Soberana Faculdade de Saúde de Petrolina, Brazil \\ E-mail: camillathaisdb@gmail.com \\ Catarina da Mota Vasconcelos Brasil \\ ORCID: https://orcid.org/0000-0003-4682-8842 \\ Soberana Faculdade de Saúde de Petrolina, Brazil \\ E-mail: catarinamvbrasil@gmail.com
}

EmillyMagalhães Silva

\begin{abstract}
Introduction: Human Papilloma Virus (HPV) is a virus prevalent in the general population and is considered a sexually transmitted infection, and can be transmitted by non-sexual forms such as casual contact and vertical transmission. The virus is considered the etiologic agent of some carcinomas, inducing the appearance of pathologies such as cervical cancer and oropharyngeal cancer. When it occurs in children, it may be the first indication of sexual abuse, emphasizing that sexual assault represents the main form of contamination by human papillomavirus (HPV) in children from five years old. Objective: To report a case of diagnosis of injury from the Human Papilloma Virus (HPV) and identification of sexual abuse in a child, with the purpose of showing the importance of pediatric dentistry in the diagnosis of violence suffered by patients, raising awareness among the dental class. Results and Discussion: The closest family members are the main responsible and often the child aggressors themselves and, therefore, it is worth noting that those responsible for mistreating their children hardly take their children to the pediatric dentist more than once, in order not to be discovered4. Thus, it is up to the professional to pay attention to the child's behaviour during the consultation and carry out detailed anamnesis and clinical examination. Final considerations: In addition, the professional has the obligation of reporting cases of abuse to the competent body, thus promoting the removal of the child abuser and preventing further episodes like this from continuing to cause traumas in them.
\end{abstract}

Keywords:Sexual Abuse; Condyloma acuminate; Child; Pediatric dentistry.

\begin{abstract}
Resumo
Introdução: O Papiloma Vírus Humano (HPV) é um vírus prevalente na população em geral, considerado uma infecção sexualmente transmissível, podendo ser transmitido por formas não sexuais, como contato casual e transmissão vertical. O vírus é considerado o agente etiológico de alguns carcinomas, induzindo o aparecimento de patologias como o câncer cervical e o câncer orofaríngeo. Quando ocorre em crianças, pode ser o primeiro indício de abuso sexual, ressaltando que a agressão sexual representa a principal forma de contaminação pelo papilomavírus humano (HPV) em crianças a partir dos cinco anos. objetivos: Relatar um caso de diagnóstico de lesão pelo Papiloma Vírus Humano (HPV) e identificação de abuso sexual em criança, com o objetivo de mostrar a importância da odontopediatria no diagnóstico da violência sofrida por pacientes, conscientizando a classe odontológica. resultados e discussão: Os familiares mais próximos são os principais responsáveis e muitas vezes os próprios agressores e, portanto, vale ressaltar que os responsáveis por maltratar seus filhos dificilmente os levam ao odontopediatra mais de uma vez, para não serem. descobertos. Assim, cabe ao profissional atentar-se ao comportamento da criança durante a consulta e realizar anamnese e exame clínico detalhados. Conclusão: O profissional tem obrigação de denunciar os casos de abuso ao órgão competente, promovendo assim o afastamento do abusador da criança e evitando que mais episódios como este continuem causando traumas nas mesmas.
\end{abstract}

Palavras-chave:Abuso sexual; Condiloma acuminado; Criança; Odontopediatria.

\section{Resumen}

Introduction: Human Papilloma Virus (HPV) is a virus prevalent in the general population and is considered a sexually transmitted infection, and can be transmitted by non-sexual forms such as casual contact and vertical transmission. The virus is considered the etiologic agent of some carcinomas, inducing the appearance of pathologies 
such as cervical cancer and oropharyngeal cancer. When it occurs in children, it may be the first indication of sexual abuse, emphasizing that sexual assault represents the main form of contamination by human papillomavirus (HPV) in children from five years old. Objective: To report a case of diagnosis of injury from the Human Papilloma Virus (HPV) and identification of sexual abuse in a child, with the purpose of showing the importance of pediatric dentistry in the diagnosis of violence suffered by patients, raising awareness among the dental class. Results anddiscussion: The closest family members are the main responsible and often the child aggressors themselves and, therefore, it is worth noting that those responsible for mistreating their children hardly take their children to the pediatric dentist more than once, in order not to be discovered4. Thus, it is up to the professional to pay attention to the child's behaviour during the consultation and carry out detailed anamnesis and clinical examination. Final Considerations: In addition, the professional has the obligation of reporting cases of abuse to the competent body, thus promoting the removal of the child abuser and preventing further episodes like this from continuing to cause traumas in them.

Palabras clave:Abuso sexual; Condiloma acuminado; Niño; Odontología pediatrica.

\section{Introduction}

Investigating the recognition, identification and notification of maltreatment in children and adolescents by health professionals, especially dentists, is a matter of paramount importance, considering that this is often the first professional to perform care in regions most affected by maltreatment, such as the head and neck (Silva, Santos, Almeida, 2019).

In Brazil, the sexual abuse of children and adolescents is one of the most worrying forms of violence. Several national studies conceptualize sexual abuse as any sexual act or game, heterosexual or homosexual relationship, whose aggressor is at a more advanced stage of psychosexual development than the child or adolescent (Santos, Dell'Áglio, 2010, p. 1).

In order for the dental surgeon to identify situations of violence, in addition to detailed anamnesis and clinical examination, he must pay attention to the child's behavior between appointments, in addition to seeking to extract from the caregiver information that can help detect something that helps in the diagnosis.

In a survey conducted by Carneiro, 2010, at the Federal University of Bahia (UFBA), to identify sexually transmitted diseases diagnosed in children who were victims of sexual abuse treated at a reference center in Pará, located in Northern Brazil, it was found that the most common pathologies were vulvovaginitis (66.2\%), followed by condylomatosis (21.5\%), gonorrhea (9.2\%), herpes (6.2\%), pelvic inflammatory disease (4.6\%) and syphilis (3.1\%). Condylomatosis, the second most noted Sexually Transmitted Infection in this study, is caused by infection with the Human Papilloma Virus (HPV).

Human Papilloma Virus (HPV) is a virus prevalent in the general population and is considered a sexually transmitted infection, and can be transmitted by non-sexual forms such as casual contact and vertical transmission. The virus is considered the etiologic agent of some carcinomas, inducing the appearance of pathologies such as cervical cancer and oropharyngeal cancer.Among the virus subtypes, those with malignant potential are: 16, 18, 31, 33, 35, 39, 45, 51, 52, 56, 58 and 59, while those with low carcinogenic risk are: 6, 11, 40, 42, 43, 44, 54, 55, 61, 62, 64, 69, 71, 72, 81, 83, 84 and 89 (Fernandes, Co sta, 2018).

Clinically, it presents itself with an exophytic lesion of an irregular character, with the appearance of a cauliflower, it is asymptomatic and it does not exceed $1 \mathrm{~cm}$ in diameter, it can appear anywhere in the oral mucosa, isolated or in multiple regions. The diagnosis of the lesion is made by clinical examination, histopathological examination, made from excisional biopsy. When it occurs in children, it may be the first indication of sexual abuse, emphasizing that sexual assault represents the main form of contamination by human papillomavirus (HPV) in children from five years old.

However, due to the lack of knowledge of these signs, the conduct to be taken in case of suspicion of violence against the child or of suffering reprisals by those responsible for the patient, such as lawsuits, many dentists do not diagnose the abuse or do not report the aggressor. 


\section{Methodology}

This is a descriptive observational case report study. For theoretical basis, a literature review was carried out using the PubMed and Scielo platforms, where reports of clinical cases of condyloma acuminatum and studies that addressed the identification of violence in children by dentists were selected to compose the discussion of the study. Works from the last 20 years were selected, but the priority in the selection was for works less than 05 years old, and among the publications used as references, the article "Conhecimento do dentistasobreviolênciainfanto-juvenil"by da Silva, Santos, Almeida, 2019, provided methodological support to this work.As this is a Clinical Case Report, there was no need for approval by the Research Ethics Committee of the institution. The case report was authorized by the patient's mother by signing the Informed Consent Form.

\section{Case Report}

Patient L.B.P.N.S., female, five years old, attended a private clinic located in the Northeast of Brazil, complaining of "a lump near the gum, in the hard palate". She reported that the injury was painless, but she experienced discomfort during chewing and physical touch.

The physical examination revealed the presence of two lesions of firm consistency, pink with whitish, sessile areas and with a rough surface, one about $0.4 \mathrm{~cm}$ in diameter and the other about $1 \mathrm{~cm}$, both located on the palatal gingiva, in the 63 region; puffs / bruises were also observed on the palate.

Figure 1: Lesion in the region of elements 53 and 63, and puffs / bruises on the palate.

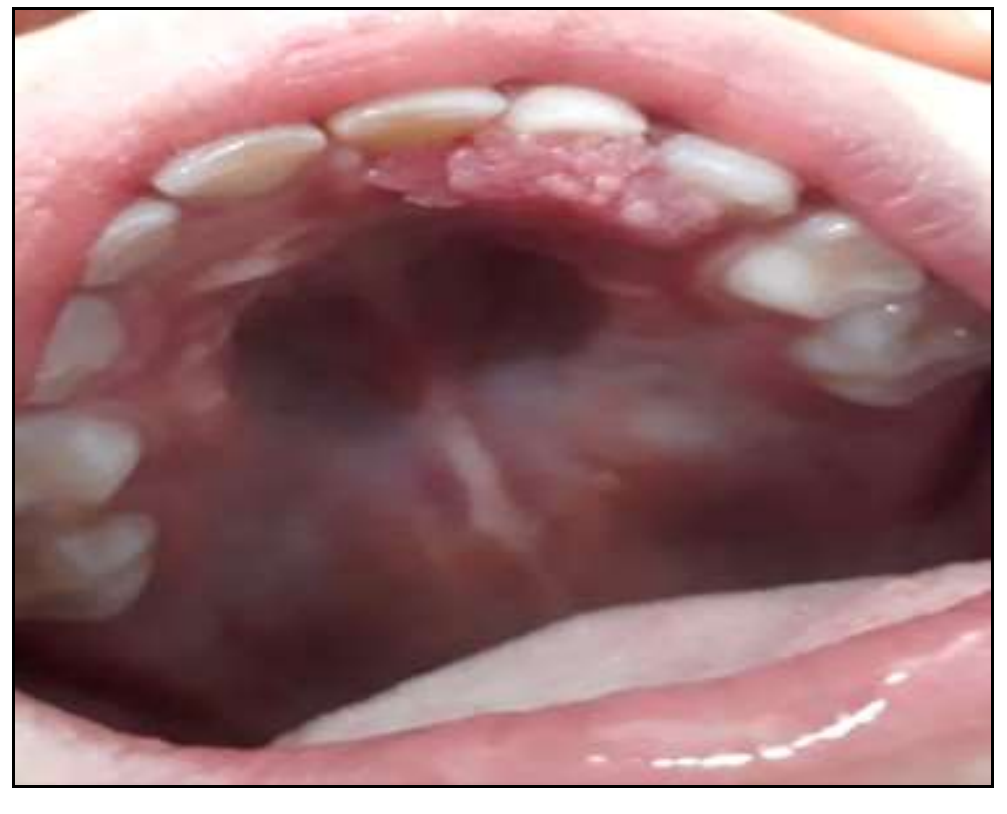

Source: Authors.

During the anamnesis, the mother reported that a relative of hers was under treatment for HPV (with active lesions), about six months before the appointment, approximately the time the child had the lesions.

Other factors that drew attention during the consultation were some statements by the child, who mentioned the close person who had HPV, without needing to mention it to the patient and the development of the habit of continuous digital interposition, observed between one consultation and another. Excision biopsies were performed and sent for histopathological analysis, which confirmed the acuminate condyloma. The professional conduct, after confirmation, was to make a complaint to Dial 100 (A Human Rights Dial), which is the body responsible for receiving and investigating reports of sexual abuse in 
Brazil. The professional talked to the child's mother, explaining the situation and the probable cause of the injuries present in her daughter and refered the patient to a free Psychology service, so that the family could be welcomed.

\section{Discussion}

Child abuse is a growing problem in all segments of society(Massoni et al., 2010) and can be classified as physical, psychological, neglect and deprivation, including sexual abuse, which is characterized as physical abuse. The closest family members are the main responsible and often the child aggressors themselves(Santos et al., 2006) and, therefore, it is worth noting that those responsible for mistreating their children hardly take their children to the pediatric dentist more than once, in order not to be discovered (Menoli et al., 2007); in addition, many cases of maltreatment that occur within the family are omitted by family members, thus presenting confusing and inconsistent reports, which do not correspond to clinical observations (Silva, Santos, Almeida, 2019). Thus, it is up to the professional to pay attention to the child's behaviour during the consultation and carry out detailed anamnesis and clinical examination.

Sexual contact is the main mode of transmission of HPV, but there are other routes such as maternal-fetal, selfinoculation from skin or genital lesions and orogenital sexual abuse(Xavier et al., 2007). Thus, it is up to the dentist to perform a complete and differential diagnosis to detect the cause of the injury; in the reported case, the patient had petechiae / ecchymosis on the palate, which may be a sign of penile pressure on the oral mucosa, resulting from fellatio. In addition, the development of the habit of continuous digital interposition, noticed between one consultation and another, was important for strengthening the diagnostic hypothesis.

There are pathognomonic signs of sexual abuse (when detected in children), such as oral manifestations of syphilis, gonorrhoea, condyloma acuminate and petechiae(Menoli et al., 2007). According to Neville, 2009, acuminated condyloma is considered an STI (sexually transmitted infection), whose lesions develop at the site of sexual contact or trauma and they can be indicative of sexual abuse when diagnosed in children(Xavier, 2007).

Despite the possibility of the patient presenting pathognomonic signs, as well as behaviors that demonstrate that he is suffering violence, many primary care dentists are not able to identify child abuse and this situation is linked to the fact that there is no broad approach on the subject in graduation (de Souza, et al., 2017). Therefore, it is necessary that there be educational practices and conversations on the subject for undergraduates and that it even addresses the importance and the obligation to report to the body responsible for investigating cases of sexual abuse (Human Rights Dial, in the case of Brazil, where what is reported in this article), which can be considered as information issued by the Health Sector or by any other body or person, to the Guardianship Council, to promote care and protection of child victims of abuse (de Souza et al., 2017).

According to Silva, Santos and Almeida, 2019, there are different reasons for dentists' hesitation to report suspected cases. In a cross-sectional and quantitative study carried out by the authors with the purpose of ascertaining the knowledge of dentistry professionals from clinics in the South and Southeast regions of Brazil about child and adolescent abuse, it was found that:

The main reasons reported were lack of adequate history, lack of adequate knowledge about abuse, lack of technical and scientific information about the dentist's role in reporting suspected cases and possible consequences for children. In addition, there is fear of lawsuits, confidentiality and also the belief that it is not the dentist's role to notify (Silva, Santos, Almeida, 2019, p. 5).

Given the above, it is considered important and necessary to know the signs of sexual abuse and other types of violence in children and the obligation to report suspected cases to the competent authorities, as was done in the reported case.The presence of HPV in oral mucosa of children should be investigated in virtue of the various forms of transmission, and 
the possibility of sexual abuse eliminated, and also of its possible relation with oral carcinoma pathogenesis in children (Pinheiro et al., 2010).

\section{Final Considerations}

Pediatric dentistry has a fundamental role with regard to the notification of child violence, since more than $50 \%$ of injuries resulting from physical abuse involve the head and face (Neto et al., 2011) regions and the professional, understanding that a child who suffers abuse will rarely externalize this in an open way, must perform a differential diagnosis. In addition, the professional has the obligation of reporting cases of abuse to the competent body, thus promoting the removal of the child abuser and preventing further episodes like this from continuing to cause traumas in them.

It was also possible to conclude that the training that dentists receive in college to identify and effectively act on cases and children who are victims of sexual abuse is little; therefore, educational actions and research in the area should be encouraged since graduation.

\section{References}

Carneiro, D. M. M. (2010). Doenças sexualmente transmissíveis em crianças e adolescentes vítimas de abuso sexual atendidas no Centro de Referência do estado do Pará. Repositório UFBA. 47 p.

da Silva, A. M., Santos, J., \& Almeida, L. H. (2019). Conhecimento do cirurgião-dentista acerca de maus-tratos à criança e ao adolescente. Revista da Faculdade de Odontologia-UPF, 24(2), 250-255.

de Souza, C. E., de Moraes Rodrigues, Í. F. M., Zocratto, K. B. F., \& de Oliveira, C. A. S. (2017). Violência infantil e a responsabilidade profissional do cirurgião-dentista-revisão de literatura. Revista Brasileira de Odontologia Legal, 4(1).

Eidt, G., Maas, J. R. S., \& Neto, L. K. (2013). Criocirurgia como tratamento de papiloma escamoso em odontopediatria: relato de caso. Revista da Faculdade de Odontologia-UPF, 18(2).

Fernandes, B. P. R. D. S. (2018). Estudo da prevalência de vírus do papiloma humano nas mãos de profissionais de saúde (Doctoraldissertation).

Jesus, L. E. D., Cirne Neto, O. L. L., Nascimento, L. M. M. D., Araújo, R. C., \& Baptista, A. A. (2001). Anogenital warts in children: sexual abuse or unintentional contamination?. Cadernos de saude publica, 17, 1383-1391.

Mass, T. J., Algayer, E., Garcia, G., \& Thereza-Bussolaro, C. (2021). Manejo de lesão papilomatosa oral em crianças. Craniofacial Research Connection Journal, 1(1), 26-40.

Massoni, A. C. D. L. T., Ferreira, Â. M. B., Aragão, A. K. R., Menezes, V. A. D., \& Colares, V. (2010). Aspectos orofaciais dos maus-tratos infantis e da negligência odontológica. Ciência \& Saúde Coletiva, 15, 403-410.

Menoli, A. P., Felipetti, F. A., Golff, F., \& Ludwig, D. (2007). Manifestações Bucais de Maus Tratos Físicos e Sexuais em Crianças - Conduta do Cirurgiãodentista. Varia Scientia, 8(14), 11-22.

Neville B. (2009). Patologia oral e maxilofacial. Elsevier. Brasil.

Neto, J. P. C. et.al. (2011). O papel do cirurgião-dentista frente aos maus tratos a criança e ao adolescente. Pergamum UNIVALE.

Santos, S. S. D., \&Dell'Aglio, D. D. (2010). Quando o silêncio é rompido: o processo de revelação e notificação de abuso sexual infantil. Psicologia \& Sociedade, 22, 328-335.

Pinheiro, R. S., França, T. R. T., Ferreira, D. C., Ribeiro, C. M. B., Leão, J. C., Castro, G. F. (2010). Human papillomavirus in the oral cavity of children. J Oral Pathol Med, 40, 121-126.

Santos, J. F., Nunes, K. S., Cavalcanti, A. L., \& Costa, E. (2006). Maus-tratos infantis: conhecimento e atitudes de odontopediatras em Uberlândia e Araguari, Minas Gerais. Pesquisa Brasileira em Odontopediatria e Clínica Integrada, 6(3), 273-279.

Xavier, S. D., Bussoloti Filho, I., Carvalho, J. M., Framil, V. M. S., \& Castro, T. M. P. G. (2007). Frequência de aparecimento de papilomavírus humano (HPV) na mucosa oral de homens com HPV anogenital confirmado por biologia molecular. ArqIntOtorrinolaringol, $1,36-44$. 